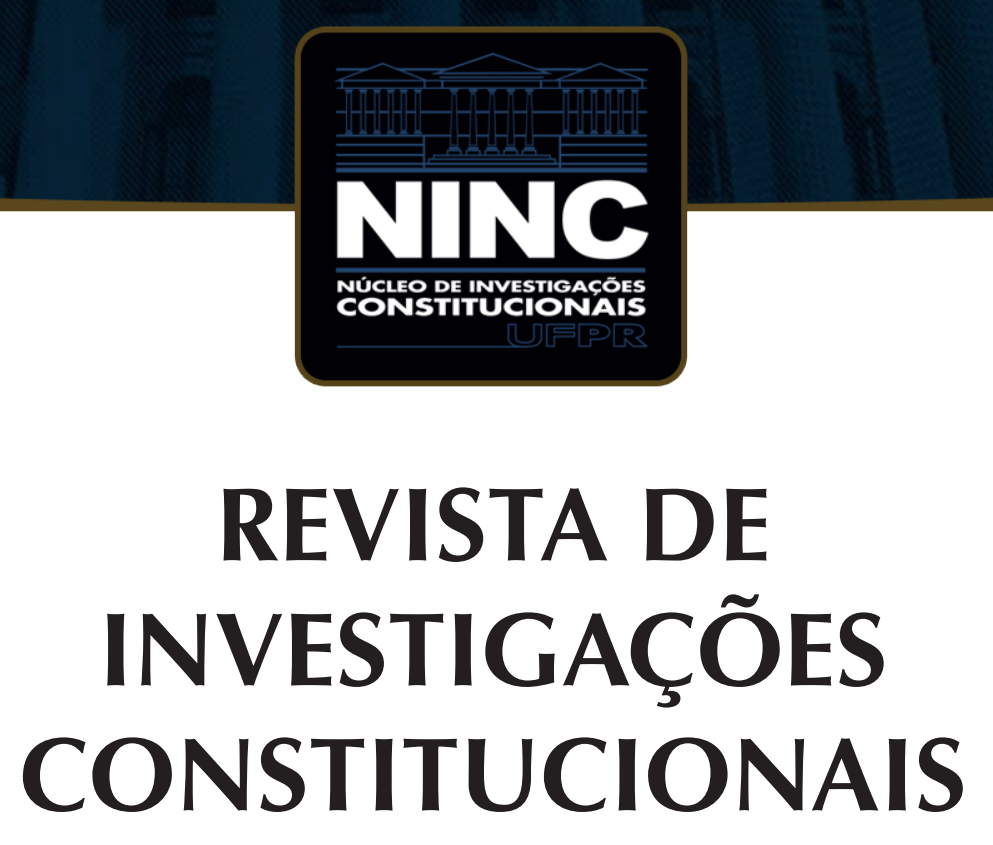

JOURNAL OF CONSTITUTIONAL RESEARCH

vol. 6 | n. 3 | setembro/dezembro 2019 | ISSN 2359-5639 | Periodicidade quadrimestral Curitiba | Núcleo de Investigações Constitucionais da UFPR | www.ninc.com.br 


\title{
Tecnologia, meio ambiente e democracia: reflexões necessárias
}

\section{Technology, environment, and democracy: some approaches}

\author{
CARLOS AUGUSTO ALCÂNTARA MACHADO ',11, " \\ ' Universidade Tiradentes (São Cristóvão-SE, Brasil) \\ "Universidade Federal de Sergipe (Brasil) \\ cmachado@infonet.com.br \\ https://orcid.org/0000-0002-2834-9699
}

\section{AUGUSTO CÉSAR LEITE DE RESENDE ${ }^{1, * *}$}

' Universidade Tiradentes (Aracaju-SE, Brasil) aclresende@bol.com.br

https://orcid.org/0000-0002-1199-7817

Recebido/Received: 08.06.2018 / June $8^{\text {th }}, 2018$ Aprovado/Approved: 17.12.2019/ December 17 $7^{\text {th }}, 2019$

\section{Resumo}

A efetividade do direito ao meio ambiente sadio depende primordialmente da implementação de políticas públicas ambientais, o que envolve o dispêndio de recursos públicos, que são escassos. Por essa razão, o presente artigo tem como objetivo principal apresentar, a partir de uma pesquisa doutrinária e legislativa, argumentos favoráveis no sentido de que a tecnologia, que está na base da atual crise ecológica, pode ser utilizada como ferramenta de minimização da reserva do possível e, por consequência, de maximização da efetividade dos direitos fundamentais. Para tanto, tratar-se-á, inicialmente,

\section{Abstract}

The effectiveness of the right to a healthy environment depends primarily on the implementation of environmental policies, which involves the expenditure of public funds, which are scarce. Therefore, this article aims to present the main, from a doctrinal and legislative research, arguments favorable to the how technology, which is the basis of the ecological crisis, can be used as a tool of mitigation of reserve possible and hence to maximize the effectiveness of fundamental rights. Thus shall be treated, initially, the relationship of technology with the environmental crisis. After, it will be to examine how information and communication

Como citar esse artigo/How to cite this article: MACHADO, Carlos Augusto Alcântara; RESENDE, Augusto César Leite de. Tecnologia, meio ambiente e democracia: reflexões necessárias. Revista de Investigações Constitucionais, Curitiba, vol. 6, n. 3, p. 749-771, set./dez. 2019. DOI: 10.5380/rinc.v6i3.59847.

* Professor de Direito Constitucional dos Cursos de Graduação e Pós-Graduação Stricto Sensu da Universidade Federal de Sergipe - UFS (São Cristóvão-SE, Brasil) e da Universidade Tiradentes - UNIT (Aracaju-SE, Brasil). Doutor em Direito pela Pontifícia Universidade Católica de São Paulo - PUC/SP. Mestre em Direito pela Universidade Federal do Ceará - UFC. Especialista em Direito de Estado pela Pontifícia Universidade Católica de São Paulo - PUC/SP. Procurador de Justiça do Ministério Público de Sergipe. E-mail: cmachado@infonet.com.br.

** Professor de Direito Constitucional do Curso de Graduação em Direito da Universidade Tiradentes - UNIT (Aracaju-SE, Brasil). Doutor em Direito pela Pontifícia Universidade Católica do Rio Grande do Sul - PUCRS. Mestre em Direito Econômico e Socioambiental pela Pontifícia Universidade Católica do Paraná - PUCPR. Especialista em Direito Público pela Universidade Sul de Santa Catarina - UNISUL. Promotor de Justiça em Sergipe. E-mail: aclresende@bol.com.br. 
da relação da tecnologia com a crise ambiental. Após, analisar-se-á o papel da tecnologia na abertura de novos espaços de participação política e de transparência administrativa. E, por fim, demonstrar-se-á que a internet é um instrumento facilitador do controle social dos gastos da Administração Pública e, por isso, de concretização do direito fundamental ao meio ambiente sadio.

Palavras-chave: tecnologia; meio ambiente; democracia; reserva do possível; controle da administração pública. technologies have enabled the opening of new spaces for political participation and administrative transparency. Finally, it will be to demonstrate that the Internet is a facilitator of social control of public spending and so the application of the fundamental right to a healthy environment.

\section{SUMÁRIO}

1. Introdução; 2. A tecnologia na base da crise socioambiental; 3. Direito fundamental ao meio ambiente sadio e a reserva do possível; 4. A internet como ferramenta de fortalecimento da democracia, da cidadania e dos direitos fundamentais; 5 . Conclusão; 6 . Referências.

\section{INTRODUÇÃO}

O tema do presente trabalho científico se inspirou no fato de que a tecnologia está na base da crise socioambiental, uma vez que as inovações tecnológicas intensificaram o ritmo de produção e consumo na sociedade contemporânea, o que está esgotando as reservas naturais e colocando em xeque a existência da vida no planeta, de modo que urge solucionar a contradição existente entre desenvolvimento econômico e preservação do meio ambiente, uma vez que o capitalismo, em regra, busca sempre o crescimento ilimitado e despreza os limites da natureza.

São necessárias a promoção do desenvolvimento sustentável e a concretização do direito fundamental ao meio ambiente sadio. A proteção do meio ambiente para as presentes e futuras gerações é, à luz do disposto no art. 225 da Constituição Federal, dever do Estado e da coletividade e a garantia do desenvolvimento nacional sustentável é, nos termos do art. $3^{\circ}$, inciso II, da Carta Política, objetivo da República Federativa do Brasil.

O Estado é, assim, constitucionalmente obrigado a empreender ações concretas, inclusive políticas públicas, voltadas à tutela da natureza, o que envolve necessariamente o dispêndio de recursos públicos, que são, por sua vez, escassos. Desse modo, a reserva do possível é verdadeiro limite à efetividade dos direitos fundamentais, especialmente os sociais e os ambientais, que são bastante custosos.

Nesse contexto, é mister levar a sério a reserva do possível ${ }^{1}$, notadamente através dos controles social e judicial das opções orçamentárias, dos gastos públicos e do

SARLET, Ingo Wolfgang. Direitos fundamentais a prestações sociais e crise: algumas aproximações. Espaço jurídico. v. 16, n. 2, p. 459-488, jul./dez. 2015, p. 472. 
cumprimento da responsabilidade fiscal, uma vez que com isso se poderá minimizar os respectivos efeitos ${ }^{2}$.

As tecnologias de informação e de comunicação produzem consequências contraditórias ao ser humano e à natureza. Elas podem ser uma ameaça aos direitos humanos e aos direitos fundamentais ${ }^{3}$ e ao mesmo tempo instrumentos de exercício da democracia e de controle da Administração Pública pelos cidadãos ${ }^{4}$.

Nesse toar, o presente artigo científico tem por finalidade precípua analisar, a partir de uma pesquisa doutrinária e legislativa, como a tecnologia pode ser utilizada como ferramenta de minimização da reserva do possível e, por consequência, de maximização da efetividade dos direitos fundamentais.

Primeiramente, tratar-se-á da crise ecológica da atualidade, haja vista a tecnologia ter aumentado a produção e o consumo, nas últimas décadas, que foram fomentados à base da destruição do meio ambiente, à custa de degradação de florestas, lagos, rios, oceanos, solo e ar, com possibilidade real de aniquilação do ser humano.

Posteriormente, discutir-se-á a necessidade de concretização do direito fundamental ao meio ambiente sadio e a interligação entre direitos fundamentais, reserva do possível e o controle das despesas públicas pela sociedade.

Em seguida, demonstrar-se-á que as tecnologias de informação e de comunicação permitiram a abertura de novos espaços de debate público e de transparência administrativa. E, por fim, analisar-se-á como a tecnologia pode ser utilizada como instrumento de controle social dos gastos da Administração Pública e, ainda, como antes destacado e por via de consequência, proporcionar a minimização da reserva do possível e maximização da efetividade dos direitos fundamentais, especialmente o direito ao meio ambiente sadio.

\section{A TECNOLOGIA NA BASE DA CRISE SOCIOAMBIENTAL}

A modernidade, que Anthony Giddens conceitua como "estilo, costume de vida ou organização social que emergiram na Europa a partir do século XVII e que ulteriormente se tornaram mais ou menos mundiais em sua influência" ${ }^{\prime \prime}$, provocou mudanças

\footnotetext{
SARLET, Ingo Wolfgang; FIGUEIREDO, Mariana Filchtiner. Reserva do possível, mínimo existencial e direito à saúde: algumas aproximações. In: SARLET, Ingo Wolfgang; TIMM, Luciano Benetti (orgs). Direito Fundamentais: orçamento e reserve do possível. 2. ed.., Porto Alegre: Livraria do Advogado, p. 13-50, 2013, p. 33-34.

3 MOLINARO, Carlos Alberto; SARLET, Ingo Wolfgang. Sociedade em rede, internet e estado de vigilância: algumas aproximações. Revista da AJURIS, Porto Alegre, vol. 40, n. 132, p. 63-87, dezembro de 2013, p. 70.

4 DUTT, Mallika; RASUL, Nadia. Conscientização digital: uma análise das oportunidades e dos riscos enfrentados pelos ativistas de direitos humanos no Brasil. SUR - Revista Internacional de Direitos Humanos, vol. 11, n. 20, p. 441-451, jun. 2014, p. 441.

5 GIDDENS, Anthony. As consequências da modernidade. Tradução: Raul Fiker. São Paulo: UNESP, 1991, p. 11.
} 
extremamente rápidas e significativas no meio social, especialmente no que toca à tecnologia 6 .

O capitalismo e a industrialização, duas dimensões da modernidade ${ }^{7}$, ensejaram avanços científicos e tecnológicos, notadamente após a Segunda Guerra Mundial, que transformaram a sociedade ocidental moderna em uma sociedade de risco e de consumo, acarretando graves problemas socioambientais.

A sociedade de consumo se caracteriza como um grupo social em estágio avançado de desenvolvimento industrial, com grande circulação e consumo de bens e serviços oferecidos graças a uma produção intensiva, pois o homem contemporâneo tem uma necessidade ilimitada de adquirir e usar inúmeros bens e serviços ${ }^{8}$.

Os produtos não são fabricados em função do seu respectivo valor de uso ou da sua utilidade, mas antes em função de seu perecimento calculado, da sua morte ${ }^{9}$. Trata-se da chamada "obsolescência programada", consistente na "prática adotada pelos fornecedores no intuito de abreviar a vida útil dos produtos, em clara prática insustentável e que visa apenas a maximização do lucro, prejudicando-se o meio ambiente e a sociedade $\mathrm{e}^{\prime 10}$.

Enfim, e na esteira dos ensinamentos de Zygmunt Bauman, "os mercados de consumo se concentram na desvalorização imediata de suas antigas ofertas, a fim de limpar a área da demanda pública para que novas ofertas a preencham"11, por meio da inserção de novos bens e serviços no mercado.

Já em 1964, Herbert Marcuse ${ }^{12}$ alertava que a sociedade industrial à época era totalitária, no sentido de que a tecnologia e a economia criavam artificialmente necessidades nas pessoas, que se tornaram manipuláveis ${ }^{13}$. Tal pensamento ainda é atual, pois os agentes econômicos se utilizam de técnicas de persuasão, através da tecnologia da comunicação e da informação, especialmente a publicidade de massa, para manipular as pessoas em prol do mercado e do lucro, afetando negativa e decisivamente a

6 GIDDENS, Anthony. As consequências da modernidade. Tradução: Raul Fiker. São Paulo: UNESP, 1991, p. 16.

7 GIDDENS, Anthony. As consequências da modernidade. Tradução: Raul Fiker. São Paulo: UNESP, 1991, p. 67.

8 FAJARDO, Elias. Consumo consciente, comércio justo: conhecimento e cidadania como fatores econômicos. Rio de Janeiro: Senac Nacional, 2010, p. 14.

9 BOUDRILLARD, Jean. A sociedade de consumo. 3.ed. Lisboa: Edições 70, 2011, p. 44.

10 EFING, Antônio Carlos; PAIVA; Leonardo Lindroth de. Consumo e obsolescência programada: sustentabilidade e responsabilidade do fornecedor. Revista de Direito, Globalização e Responsabilidade nas Relações de Consumo, Curitiba, v. 2, n. 2, p. 117-135, jul./dez. 2016, p. 118.

11 BAUMAN, Zygmunt. Vida para o consumo: a transformação das pessoas em mercadoria. Rio de Janeiro: Zahar, 2008, p. 128.

12 MARCUSE, Herbert. $\mathbf{O}$ homem unidimensional: estudos da ideologia da sociedade industrial avançada. São Paulo: EDIPRO, 2015.

13 BRESSER-PEREIRA, Luiz Carlos. Revoluções utópicas dos anos 60: a revolução estudantil e a revolução política na igreja. 3. ed. São Paulo: Editora 34, 2006, p. 82. 
liberdade dos indivíduos no que toca à liberdade de escolha na aquisição de bens e serviços. Isto porque a sociedade e as empresas produzem carências e desejos, passando as pessoas a serem julgadas por aquilo que consomem, vestem ou calçam, pelos locais que frequentam, pelos bens materiais que exibem em público ${ }^{14}$.

Os indivíduos são incentivados pelos diversos veículos de publicidade a consumir cada vez mais, de modo que a tecnologia da comunicação de massa passa a ser usada para aumentar os lucros das grandes corporações, pois, como refere Jean Boudrillard, a "publicidade realiza o prodígio de um orçamento considerável gasto com o único fim, não de acrescentar, mas de tirar o valor de uso dos objectos, de diminuir o seu valor/tempo, sujeitando-se ao valor/moda e à renovação acelerada"15, já que incute na mente das pessoas que os seus produtos se tornaram defasados, induzindo-as, assim, a adquirir novos produtos.

A sobrevivência da sociedade de consumo depende da criação de falsas necessidades por novas mercadorias. É preciso, pois, embutir na consciência dos homens a necessidade de adquirir novos bens e serviços, a fim de que o produto, ao ser inserido no mercado, seja ao máximo consumido e, em seguida, substituído por outra mercadoria ${ }^{16}$.

Zygmunt Bauman afirma que "o consumo é uma condição, e um aspecto, permanente e irremovível, sem limites temporais ou históricos; um elemento inseparável da sobrevivência biológica que nós humanos compartilhamos com todos os outros organismos vivos"17, ou seja, é uma necessidade vital do ser humano. Consume-se para viver.

O consumismo, acrescente-se, conceituado por Fátima Portilho, como a "expansão de um conjunto de valores hedonistas que estimula o indivíduo, ou a sociedade, a buscar satisfação e felicidade através da aquisição e exibição pública de uma grande quantidade de bens e serviços"18, passou a ser, inegavelmente, um dos principais problemas da sociedade moderna.

Hoje, os indivíduos consomem com os olhos e emoções, quase sempre voltados apenas para eles mesmos, num ato extremamente individualista e egoísta, sem

\footnotetext{
14 BRASIL. Ministério do Meio Ambiente. Consumo sustentável: manual de educação. Brasília: Consumers International/MMA/MEC/IDEC, 2005, p. 15. Disponível em: <http://portal.mec.gov.br/dmdocuments/publicacao8.pdf $>$. Acesso em 07 de junho de 2018.

15 BOUDRILLARD, Jean. A sociedade de consumo. 3.ed. Lisboa: Edições 70, 2011, p. 45.

16 PORTILHO, Fátima. Sustentabilidade ambiental, consumo e cidadania. 2.ed. São Paulo: Cortez, 2010, p. 21-22.

17 BAUMAN, Zygmunt. Vida para o consumo: a transformação das pessoas em mercadoria. Rio de Janeiro: Zahar, 2008, p. 37.

18 PORTILHO, Fátima. Sustentabilidade ambiental, consumo e cidadania. 2.ed. São Paulo: Cortez, 2010, p. 25.
} 
se preocupar com as consequências socioambientais de suas decisões de consumo ${ }^{19}$. Vive-se, por assim dizer, em uma cultura de consumismo, associada, de igual forma, a uma cultura do descarte.

Ademais, o desenvolvimento industrial, tecnológico e científico ensejou, a partir da segunda metade do século $X X$, a transformação da sociedade industrial em uma sociedade de risco. As atividades humanas produzem riscos à vida dos elementos humanos e não humanos da natureza, que transbordam, inclusive, as fronteiras de tempo e espaço ${ }^{20}$, ou seja, as ameaças são globalizantes, supranacionais e independentes de classe, como destaca Ulrich Beck ${ }^{21}$.

Os riscos produzidos na atualidade não são unicamente concretos e sensorialmente perceptíveis, mas também invisíveis, incertos e imprevisíveis, escapando completamente à percepção humana imediata ${ }^{22}$. Além disso, os riscos decorrentes da ações humanas contêm um efeito bumerangue, na medida em que eles alcançarão, inevitavelmente, todos aqueles que os produziram ou que lucraram com eles, inclusive sob a forma de ameaças ecológicas ${ }^{23}$.

A atual crise socioambiental é agravada, pelo que Ulrich Beck chama de "irresponsabilidade organizada" 24 , na medida em que reflete o processo de ocultamento ou dissimulação, pelo Estado e pelos particulares, das consequências dos perigos ecológicos de larga escala advindas das atividades dos homens, especialmente dos avanços tecnológicos, a fim de atender seus interesses econômicos e políticos ${ }^{25}$.

Enfim, a tecnologia está na base da crise socioambiental da atualidade. Contudo, a tecnologia é construída e desenvolvida pelos seres humanos de acordo com seus interesses, valores e objetivos, de modo que ela não produz somente consequências negativas ao homem e à natureza. A tecnologia também pode promover impactos positivos na sociedade, notadamente para os direitos fundamentais e para a democracia.

\footnotetext{
19 EFING, Antônio Carlos; RESENDE, Augusto César Leite de. Educação para o consumo consciente: um dever do Estado. Revista de Direito Administrativo - RDA, Rio de Janeiro, v. 269, p. 197-224, maio/ago. 2015, p. 210.

20 BAGGIO, Andreza Cristina. A sociedade de risco e a confiança nas relações de consumo. Revista de Direito Econômico e Socioambiental, Curitiba, v. 1, n.1, p. 127-147, jan./jun. 2010, p. 131.

21 BECK, Ulrich. Sociedade de risco: rumo a uma outra modernidade. São Paulo: 34, 2010, p. 16.

22 BECK, Ulrich. Sociedade de risco: rumo a uma outra modernidade. São Paulo: 34, 2010 , p. 27.

23 BECK, Ulrich. Sociedade de risco: rumo a uma outra modernidade. São Paulo: 34, 2010 , p. 27.

24 BECK, Ulrich. Ecological Politics in an Age of Risk. Londres: Polity Publications, 1995.

25 SILVEIRA, Clóvis Eduardo Malinverni da. Processos coletivos para a tutela do risco ecológico: a construção de um patrimônio comum coletivo. 2011. 441f. Tese (Doutorado em Direito) - Universidade Federal de Santa Catarina, Centro de Ciências Jurídicas. Programa de Pós-Graduação em Direito. Florianópolis, p. 42.
} 


\section{DIREITO FUNDAMENTAL AO MEIO AMBIENTE SADIO E A RE- SERVA DO POSSÍVEL}

No Estado liberal do século XIX, a lei era a fonte hegemônica do Direito e passou a ser o instrumento utilizado para aplicar e interpretar a Constituição, limitar o poder estatal e manifestar a vontade popular ${ }^{26}$, de maneira que o pensamento jurídico vigente até primeira metade do século XX, o positivismo jurídico, fundava-se na ideia da observância quase "cega" da lei, afastando do Direito a filosofia, os princípios, os valores e o sentido de Justiça ${ }^{27}$.

A negativa de abertura do sistema jurídico aos valores permitiu que o Estado produzisse um Direito marcado pela tirania e pelo descarte do ser humano ${ }^{28}$. Nesse cenário, tem-se a ascensão do fascismo ao poder, na Itália, e do nazismo, na Alemanha, que retiravam da "lei" o fundamento de validade das atrocidades praticadas contra negros, ciganos, homossexuais e, notadamente, judeus durante a Segunda Guerra Mundial.

As concepções da infalibilidade do legislador, da lei como fonte única do Direito e de um ordenamento jurídico indiferente a valores éticos promoveram o fracasso político do positivismo jurídico porquanto não mais se aceitava, no pensamento jurídico do pós-guerra, tais ideias ${ }^{29}$.

Por essa razão, o constitucionalismo mundial sofreu grandes e profundas transformações, após a Segunda Guerra Mundial, com o surgimento do pós-positivismo, que promoveu o rompimento da separação do ser e do dever ser defendido pelo positivismo jurídico com a reaproximação entre o Direito e a ética e entre o Direito e a moral, exigindo-se, agora, uma leitura social, humana e moral do Direito, isto é, vai-se além da estrita legalidade, mas não se descuida do direito posto ${ }^{30}$.

Tem-se a abertura do Direito aos valores. E os valores vigentes na sociedade estão referenciados no Preâmbulo da Constituição Federal de 1988 e positivados, expressa ou implicitamente, na própria Carta Constitucional na forma de princípios. Desse

\footnotetext{
26 MÖLLER, Max. Teoria geral do neoconstitucionalismo: bases teóricas do constitucionalismo contemporâneo. Porto Alegre: Livraria do Advogado, 2011, p. 24.

27 BARROSO, Luís Roberto. Curso de direito constitucional contemporâneo: os conceitos fundamentais e a construção do novo modelo. 4. ed.. São Paulo: Saraiva, 2013, p. 262.

28 ARONNE, Ricardo; MORAES, Denise Bermudez de Oliveira. A valsa do leviatã pós-moderno: velhos cisnes ônticos sobre novos lagos epistêmicos. Revista da Faculdade de Direito - UFPR, Curitiba, n. 56, p. 127-140, 2012, p. 135.

29 BARROSO, Luís Roberto. Curso de direito constitucional contemporâneo: os conceitos fundamentais e a construção do novo modelo. 4. ed.. São Paulo: Saraiva, 2013, p. 264.

30 BARROSO, Luís Roberto. Curso de direito constitucional contemporâneo: os conceitos fundamentais e a construção do novo modelo. 4. ed.. São Paulo: Saraiva, 2013, p. 270-272.
} 
modo, os valores fundantes do sistema jurídico brasileiro condicionam a compreensão e a interpretação dos textos normativos, especialmente do Direito Privado ${ }^{31}$.

Os valores são preexistentes às regras e aos princípios. Eles integram a norma, mas não são normas jurídicas ${ }^{32}$. Os valores influenciam a construção dos significados nos textos normativos, razão pela qual se houver alteração dos valores que permeiam a vida em sociedade e fundamentam o sistema, ter-se-á modificação do sentido das normas ${ }^{33}$.

Uma das grandes mudanças de paradigma, ocorridas na segunda metade do século XX, foi o reconhecimento da força normativa da Constituição e dos princípios. Konrad Hesse assentou que "a Constituição jurídica logra converter-se, ela mesma, em força ativa, que se assenta na natureza singular do presente (individuelle Beschffenheit der Gegenwart). Embora a Constituição não possa, por si só, realizar nada, ela pode impor tarefas" ${ }^{\prime \prime}$.

A Constituição é, indiscutivelmente, uma norma jurídica e, como tal, dotada de imperatividade e que, por isso mesmo, seus preceitos são obrigatórios e vinculativos. Não se trata de mero documento político, de um simples convite ao administrador público a dar plena efetividade ao princípio da dignidade da pessoa humana e aos direitos fundamentais nela consagrados, cuja concretização fica ao alvedrio, ou melhor, sob a discricionariedade do chefe do Poder Executivo.

Sob a influência do neoconstitucionalismo e da redemocratização do Brasil, a Constituição Federal de 1988 consagrou um amplo e extenso leque de direitos fundamentais de primeira, segunda e terceira dimensões, impondo ao Poder Público o dever de adotar medidas efetivas e adequadas de proteção e promoção de tais direitos fundamentais.

A dignidade da pessoa humana não é, ela mesma, um direito fundamental ${ }^{35}$, mas, enquanto princípio fundamental do Estado brasileiro ${ }^{36}$, é a fonte e a base dos

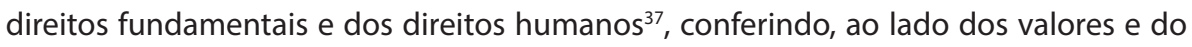

\footnotetext{
31 ARONNE, Ricardo. Sistema jurídico e unidade axiológica: os contornos metodológicos do direito civil constitucional. Revista do Instituto do Direito Brasileiro, Lisboa, Ano 2, n. 1, p. 73-113, 2013, p. 80.

32 ARONNE, Ricardo. Sistema jurídico e unidade axiológica: os contornos metodológicos do direito civil constitucional. Revista do Instituto do Direito Brasileiro, Lisboa, Ano 2, n. 1, p. 73-113, 2013, p. 95.

33 ARONNE, Ricardo. Sistema jurídico e unidade axiológica: os contornos metodológicos do direito civil constitucional. Revista do Instituto do Direito Brasileiro, Lisboa, Ano 2, n. 1, p. 73-113, 2013, p. 96.

34 HESSE, Konrad. A força normativa da Constituição, Tradução: Gilmar Ferreira Mendes, Sérgio Antônio Frabris Editor, Porto Alegre, 1991, p. 19.

35 SARLET, Ingo Wolfgang. Dignidade da pessoa humana e direitos fundamentais na Constituição Federal de 1988. 9. ed.. Porto Alegre: Livraria do Advogado, 2012, p. 84.

36 ARONNE, Ricardo; MORAES, Denise Bermudez de Oliveira. A valsa do leviatã pós-moderno: velhos cisnes ônticos sobre novos lagos epistêmicos. Revista da Faculdade de Direito - UFPR, Curitiba, n. 56, p. 127-140, 2012, p. 96.

37 SARLET, Ingo Wolfgang. Dignidade da pessoa humana e direitos fundamentais na Constituição Federal de 1988. 9. ed.. Porto Alegre: Livraria do Advogado, 2012, p. 95.
} 
princípio estruturante do Estado Social Democrático de Direito, sentido e legitimidade à ordem constitucional ${ }^{38}$.

A dignidade da pessoa humana tem uma dimensão ecológica, que alberga a qualidade de vida e a higidez do ambiente em que a vida, humana e não humana, desenvolve-se, ou seja, a qualidade de vida é elemento normativo integrante do princípio da dignidade da pessoa humana ${ }^{39}$. Desse modo, faz-se mister a existência de um ambiente equilibrado e seguro para que existam condições bióticas e abióticas favoráveis ao desenvolvimento pleno da vida com qualidade e, consequentemente, com dignidade.

O direito ao meio ambiente sadio está diretamente fulcrado no princípio da dignidade da pessoa humana porque essencial à qualidade de vida e à própria existência humana. Não há que se falar em dignidade humana, se não houver um ambiente favorável ao bem-estar, à saúde e à vida humana, isto é, que proporcione ao homem uma sadia qualidade de vida. Assim não se pode negar a fundamentalidade material do direito ao meio ambiente sadio.

$\mathrm{O}$ direito ao meio ambiente ecologicamente equilibrado, típico direito fundamental de terceira dimensão, assim como os direitos civis e políticos (primeira dimensão) e os direitos econômicos, sociais e culturais (segunda dimensão), implica para o Estado as obrigações: a) de respeitar o direito, ou seja, de não os violar, por meio de sua conduta; b) de proteger o direito das agressões de terceiros; e c) de satisfazer o direito, cujos casos de violações decorrem, como regra, de omissões do Estado ${ }^{40}$, o que envolve necessariamente o dispêndio de recursos públicos.

$\mathrm{Na}$ verdade, o efetivo exercício de todos os direitos fundamentais, sejam eles civis, políticos, econômicos, sociais, culturais ou ambientais, custa dinheiro e, por consequência, envolve o gasto de recursos públicos ${ }^{41}$. O Estado, porém, dispõe apenas de limitada capacidade de dispor sobre o objeto das prestações reconhecidas pelas normas definidoras de direitos fundamentais, notadamente, os direitos sociais e ambientais, de tal sorte que a limitação dos recursos constitui limite jurídico e fático dos

\footnotetext{
38 EHRHARDT JÚNIOR, Marcos. Acertos e desacertos do processo de constitucionalização dos direitos: uma reflexão sobre os perigos da ubiquidade constitucional no direito civil brasileiro. Revista do Instituto do Direito Brasileiro, Lisboa, Ano 1, n. 1, p. 833-865, 2012, p. 844.

39 SARLET, Ingo Wolfgang; FENSTERSEIFER, Tiago. Direito constitucional ambiental: Constituição, direitos fundamentais e proteção do ambiente. 2. ed.. São Paulo: Revista dos Tribunais, 2012, p. 89.

40 ABRAMOVICH, Víctor; COURTIS, Christian. Los derechos sociales como derechos exigibles. 2. ed.. Madrid: Trotta, 2004, p. 133-134.

41 HOLMES, Stephen; SUNSTEIN, Cass R. The cost of rights: why liberty depends on taxes. New York: W. W. Norton \& Company, 1999, p. 15.
} 
direitos fundamentais ${ }^{42}$. É a chamada reserva do possível, uma das faces ocultas dos direitos fundamentais ${ }^{43}$.

Como ensina Ana Paula de Barcellos, existem duas espécies da reserva do possível, a fática e a jurídica. A primeira refere-se à inexistência material e real de recursos, ou seja, indisponibilidade de caixa. A segunda compreende a inexistência de autorização orçamentária para a realização de determinada despesa ${ }^{44}$.

Assim, a concretização dos direitos fundamentais e a execução das demais tarefas do Estado exigem o financiamento do próprio Estado por meio dos tributos. Por isso, a tributação é tradicionalmente pensada como forma de arrecadação de receitas para o custeio das atividades estatais e, mais recentemente, como formas de indução de condutas virtuosas ou de desestímulo de comportamentos inadequados, inconvenientes ou inoportunos ${ }^{45}$.

O Estado precisa arrecadar para custear a implementação dos direitos fundamentais e a arrecadação se fará, principalmente, por meio da tributação ${ }^{46}$. A tributação é utilizada, portanto, para financiar a satisfação dos direitos fundamentais, aumentando a disponibilidade de caixa e, por consequência, as possibilidades de cumprimento dos direitos fundamentais. Por tais motivos, há clara relação entre a reserva do possível, os direitos fundamentais e a tributação ${ }^{47}$.

A crise de efetividade dos direitos fundamentais está diretamente relacionada com a carência de recursos públicos necessários para a execução de políticas públicas sociais $^{48}$. Assim, levar os direitos fundamentais a sério significa, na lição de Holmes e Sustein, levar a sério o problema de escassez de recursos públicos ${ }^{49}$. E levar a sério a reserva do possível significa que cabe ao Estado comprovar a insuficiência de recursos

42 SARLET, Ingo Wolfgang. A eficácia dos direitos fundamentais: uma teoria geral dos direitos fundamentais na perspectiva constitucional. 12. ed. Porto Alegre: Livraria do Advogado, 2015, p. 296.

43 NABAIS, José Casalta. A face oculta dos direitos fundamentais: os deveres e os custos dos direitos. Revista de Direito Público da Economia - RDPE. Belo Horizonte, ano 5, n. 20, p. 153-181, out./dez. 2007.

44 BARCELLOS, Ana Paula de. A eficácia jurídica dos princípios constitucionais: o princípio da dignidade da pessoa humana. 2. ed.. Rio de Janeiro: Renovar, 2008, p. 262-263.

45 CALIENDO, Paulo. Limitações constitucionais ao poder com finalidade extrafiscal. Nomos - Revista do Programa de Pós-Graduação em Direito da Universidade Federal do Ceará. vol. 33, n. 02, p. 171-206, jul./dez. 2013, p. 172.

46 CALIENDO, Paulo. Reserva do possível, direitos fundamentais e tributação. In: SARLET, Ingo Wolfgang; TIMM, Luciano Benetti (org.). Direitos fundamentais, orçamento e "reserva do possível". Porto Alegre: Livraria do Advogado, p. 195-208, 2008, p. 204.

47 CALIENDO, Paulo. Reserva do possível, direitos fundamentais e tributação. In: SARLET, Ingo Wolfgang; TIMM, Luciano Benetti (org.). Direitos fundamentais, orçamento e "reserva do possível". Porto Alegre: Livraria do Advogado, p. 195-208, 2008, p. 206.

48 SARLET, Ingo Wolfgang. Direitos fundamentais a prestações sociais e crise: algumas aproximações. Espaço jurídico. v. 16, n. 2, p. 459-488, jul./dez. 2015, p. 472.

49 SARLET, Ingo Wolfgang. Direitos fundamentais a prestações sociais e crise: algumas aproximações. Espaço jurídico. v. 16, n. 2, p. 459-488, jul./dez. 2015, p. 473. 
públicos necessários à concretização dos direitos fundamentais, bem como o uso eficiente e correto de tais recursos ${ }^{50}$.

É dever jurídico do Estado agir pautado nos princípios constitucionais da moralidade, da eficiência, da publicidade e da transparência em relação aos gastos públicos e à escassez de recursos financeiros, com o objetivo de garantir em nível satisfatório a efetividade dos direitos sociais e ambientais ${ }^{51}$.

A publicidade e a transparência permitem o controle judicial e, sobretudo, o social sobre as opções orçamentárias do Administrador Público e sobre o cumprimento da legislação relativa aos gastos públicos e à responsabilidade fiscal. Desse modo, o controle social da Administração Pública é instrumento necessário para a minimização dos efeitos da reserva do possível ${ }^{52}$.

Nesse contexto, a tecnologia pode ser utilizada como um útil mecanismo de controle social do Estado, de minimização da reserva do possível e, por consequência, de maximização da efetividade dos direitos fundamentais?

\section{A INTERNET COMO FERRAMENTA DE FORTALECIMENTO DA DE- MOCRACIA, DA CIDADANIA E DOS DIREITOS FUNDAMENTAIS}

Na lição de José Joaquim Gomes Canotilho, a Constituição portuguesa é um sistema interno de regras e princípios de diferentes graus de densidade normativa, que se assenta em princípios estruturantes, que, por sua vez, ganham concretização através dos princípios constitucionais gerais, que se densificam através dos princípios constitucionais especiais, e que, por fim, se concretizam por meio das regras constitucionais ${ }^{53}$.

No que toca ao sistema jurídico brasileiro, Ricardo Aronne ensina que o princípio estruturante, enfeixador dos valores constitucionalmente garantidos, é o princípio do Estado Social Democrático de Direito e fonte normativa da ordem jurídica brasileira. Os princípios fundamentais decorrem do princípio estruturante e são as bases do ordenamento jurídico nacional; os princípios gerais densificam, por sua vez, os fundamentais e visam concretizá-los, dentre os quais se destacam os princípios da liberdade e da igualdade. Os princípios especiais explicitam os gerais em ramos específicos do Direito. As regras são normas jurídicas que regulam condutas, fatos ou atos. E, por fim,

50 SARLET, Ingo Wolfgang. Direitos fundamentais a prestações sociais e crise: algumas aproximações. Espaço jurídico. v. 16, n. 2, p. 459-488, jul./dez. 2015, p. 474.

51 SARLET, Ingo Wolfgang. Direitos fundamentais a prestações sociais e crise: algumas aproximações. Espaço jurídico. v. 16, n. 2, p. 459-488, jul./dez. 2015, p. 473.

52 SARLET, Ingo Wolfgang. Direitos fundamentais a prestações sociais e crise: algumas aproximações. Espaço jurídico. v. 16, n. 2, p. 459-488, jul./dez. 2015, p. 474.

53 CANOTILHO, José Joaquim Gomes. Direito constitucional e teoria da Constituição. 7. ed., Coimbra: Almedina, 2011, p. 1173-1174. 
as normas individuais são as decisões judiciais e as disposições contratuais e, portanto, regentes de casos concretos ${ }^{54}$.

A República Federal do Brasil se constitui em Estado Social e Democrático de Direito, princípio este em que se assenta a ordem jurídica nacional, porque todo poder emana do povo, que o exerce por meio de seus representantes eleitos ou diretamente, nos termos do parágrafo único do art. $1^{\circ}$ da Constituição Federal.

A opção do legislador constituinte foi adotar primeiramente a chamada democracia indireta ou representativa, ante a impossibilidade real e prática da adoção da democracia direta em sua plenitude porque entendeu, ao que parece, ser inviável a convocação de constantes pronunciamentos diretos do povo sobre todos os aspectos da vida político-institucional do Estado.

Na democracia representativa, o povo participa do processo de formação das decisões políticas do Estado indiretamente, isto é, através de seus representantes eleitos para, em seu nome, tomar decisões e externar a vontade popular, como se o povo estivesse realmente governando.

A Constituição da República adotou, porém, institutos de participação direta do povo na vida política do Estado, tais como o referendo, o plebiscito, a iniciativa popular (art. 14, I, II e III - CF) e a ação popular (art. 5, LXXIII - CF), característicos da democracia direta (ou da democracia semidireta, para ser mais preciso), mas que não permitem a ampla e plural discussão popular sobre todas as questões controversas no seio da sociedade.

A Carta Magna também permite a abertura de espaços públicos, onde os indivíduos possam, no pleno exercício da cidadania, conjuntamente e em igualdade, dialogar e discutir entre si, participando e influenciando diretamente na tomada de decisões políticas e jurídicas do Estado ${ }^{55}$.

54 ARONNE, Ricardo; MORAES, Denise Bermudez de Oliveira. A valsa do leviatã pós-moderno: velhos cisnes ônticos sobre novos lagos epistêmicos. Revista da Faculdade de Direito - UFPR, Curitiba, n. 56, p. 127-140, 2012, p.96-97.

55 Sobre o tema e desenvolvendo a matéria no campo da democracia participativa, ver o estudo de MACHADO, Carlos Augusto Alcântara. Fraternidade e Democracia: Considerações sobre os mecanismos de participação popular e fraterna na Carta Constitucional do Brasil de 1988. In: VERONESE, Josiane Rose Petry; OLIVEIRA, Olga Maria Boschi Aguiar de; MOTA, Sergio Ricardo Ferreira. O Direito no Século XXI - O que a Fraternidade tem a dizer. Florianópolis: Editora Insular, 2016, p. 67-69: "[...] as situações que materializaram o compromisso constituinte com a democracia participativa não se limitaram aos institutos antes comentados. Ao longo de todo o texto constitucional é possível encontrar dispositivos que conclamam a sociedade civil, mais especificamente a cidadania, a se apresentar como protagonista da gestão pública, emprestando a sua valiosa colaboração na construção das decisões, integrando Conselhos Populares, exercendo controle social sobre determinados atos do governo ou, mesmo, mediando deliberações onde os interesses sociais estejam em jogo. Disposições constitucionais afinadas nesse diapasão se apresentam ao longo do texto originário da Constituição Federal ou resultado de Emendas Constitucionais (EC) promulgadas em momento posterior, todas adiante identificadas: a) Direito de ingresso de Ação Popular: "Art. 50. (...): LXXIII - qualquer cidadão é parte legítima para propor ação popular que vise a anular ato lesivo ao patrimônio público ou de entidade de que o Estado participe, à moralidade administrativa, ao meio ambiente e ao patrimônio histórico e cultural, ficando o autor, salvo comprovada má-fé, isento de custas judiciais e do ônus da sucumbência"; b) Participação obrigatória de 


\section{Hannah Arendt explica a distinção entre espaço público e espaço privado a}

organizações sindicais nas negociações coletivas de trabalho: "Art. $8^{\circ} E$ Elivre a associação profissional ou sindical, observado o seguinte: (...); VI - é obrigatória a participação dos sindicatos nas negociações coletivas de trabalho"; c) Direito de Participação dos trabalhadores e empregadores nos colegiados de órgãos públicos: "Art. 10. É assegurada a participação dos trabalhadores e empregadores nos colegiados dos órgãos públicos em que seus interesses profissionais ou previdenciários sejam objeto de discussão e deliberação"; d) Controle Social das Contas Públicas: "Art. 31. (...). § $3^{\circ}$ - As contas dos Municípios ficarão, durante sessenta dias, anualmente, à disposição de qualquer contribuinte, para exame e apreciação, o qual poderá questionar-lhes a legitimidade, nos termos da lei"; e) Direito de Participação do Usuário de Serviços Públicos: "Art. 37. (...). § 3․ A lei disciplinará as formas de participação do usuário na administração pública direta e indireta, regulando especialmente: I - as reclamações relativas à prestação dos serviços públicos em geral, asseguradas a manutenção de serviços de atendimento ao usuário e a avaliação periódica, externa e interna, da qualidade dos serviços; Il - o acesso dos usuários a registros administrativos e a informações sobre atos de governo, observado o disposto no art. 5०, X e XXXIII; III - a disciplina da representação contra o exercício negligente ou abusivo de cargo, emprego ou função na administração pública" (Redação dada pela Emenda Constitucional no 19/1998); f) Denúncia de irregularidades: “Art. 74. (...). § 2º- Qualquer cidadão, partido político, associação ou sindicato é parte legítima para, na forma da lei, denunciar irregularidades ou ilegalidades perante o Tribunal de Contas da União"; g) Participação na gestão da seguridade social: "Art. 194. A seguridade social compreende um conjunto integrado de ações de iniciativa dos Poderes Públicos e da sociedade, destinadas a assegurar os direitos relativos à saúde, à previdência e à assistência social. Parágrafo único. Compete ao Poder Público, nos termos da lei, organizar a seguridade social, com base nos seguintes objetivos: (...); VII - caráter democrático e descentralizado da administração, mediante gestão quadripartite, com participação dos trabalhadores, dos empregadores, dos aposentados e do Governo nos órgãos colegiados" (Redação dada pela EC n²0, de 1998); h) Participação na gestão do Serviço Único de Saúde: "Art. 198. As ações e serviços públicos de saúde integram uma rede regionalizada e hierarquizada e constituem um sistema único, organizado de acordo com as seguintes diretrizes: (...); III - participação da comunidade"; i) Participação da Sociedade na formulação das políticas públicas de Assistência Social e no controle de tais ações: "Art. 204. As ações governamentais na área da assistência social serão realizadas com recursos do orçamento da seguridade social, previstos no art. 195, além de outras fontes, e organizadas com base nas seguintes diretrizes: (...); II - participação da população, por meio de organizações representativas, na formulação das políticas e no controle das ações em todos os níveis"; j) Participação na gestão do Ensino Público: "Art. 206. O ensino será ministrado com base nos seguintes princípios: (...); VI - gestão democrática do ensino público, na forma da lei"; k) Promoção e proteção do patrimônio cultural: "Art. 216. Constituem patrimônio cultural brasileiro os bens de natureza material e imaterial, tomados individualmente ou em conjunto, portadores de referência à identidade, à ação, à memória dos diferentes grupos formadores da sociedade brasileira, nos quais se incluem: (...). § $1^{\circ}$ - O Poder Público, com a colaboração da comunidade, promoverá e protegerá o patrimônio cultural brasileiro, por meio de inventários, registros, vigilância, tombamento e desapropriação, e de outras formas de acautelamento e preservação"; I) Participação na gestão e controle de Políticas Públicas de Cultura: "Art. 216-A. O Sistema Nacional de Cultura, organizado em regime de colaboração, de forma descentralizada e participativa, institui um processo de gestão e promoção conjunta de políticas públicas de cultura, democráticas e permanentes, pactuadas entre os entes da Federação e a sociedade, tendo por objetivo promover o desenvolvimento humano, social e econômico com pleno exercício dos direitos culturais. § $1^{\circ}$ O Sistema Nacional de Cultura fundamenta-se na política nacional de cultura e nas suas diretrizes, estabelecidas no Plano Nacional de Cultura, e rege-se pelos seguintes princípios: (...); $X$ - democratização dos processos decisórios com participação $e$ controle social"; (Dispositivos incluídos pela EC no 71, de 2012); m) Participação social no Conselho Consultivo do Fundo de Combate e Erradicação da Pobreza: Ato das Disposições Constitucionais Transitórias - ADCT "Art. 79. É instituído, para vigorar até o ano de 2010, no âmbito do Poder Executivo Federal, o Fundo de Combate e Erradicação da Pobreza, a ser regulado por lei complementar com o objetivo de viabilizar a todos os brasileiros acesso a níveis dignos de subsistência, cujos recursos serão aplicados em ações suplementares de nutrição, habitação, educação, saúde, reforço de renda familiar e outros programas de relevante interesse social voltados para melhoria da qualidade de vida (Incluído inicialmente pela EC n 31/2000, com alteração da Emenda Constitucional nº 42/2003 e da Emenda Constitucional n 67/2010). Parágrafo único. O Fundo previsto neste artigo terá Conselho Consultivo e de Acompanhamento que conte com a participação de representantes da sociedade civil, nos termos da lei" (Incluído pela EC n 31/2000); n) Participação social na gestão do Fundo Estadual e Municipal de Combate à Pobreza: ADCT - "Art. 82. Os Estados, o Distrito Federal e os Municípios devem instituir Fundos de Combate à Pobreza, com os recursos de que trata este artigo e outros que vierem a destinar, devendo os referidos Fundos ser geridos por entidades que contem com a participação da sociedade civil" (Incluído pela EC n 31/2000)". 
partir do conceito de vita activa, que é utilizada para designar as três atividades humanas fundamentais: trabalho, obra e ação. Segundo a referida filósofa, o trabalho e a obra se situam no espaço privado porque o trabalho é a atividade desenvolvida pelo homem para satisfazer as necessidades vitais e biológicas humanas, enquanto que a obra é a atividade de transformação da natureza pelo homem, proporcionando a criação de um mundo não natural, a fabricação de bens artificiais ${ }^{56}$. Por fim, "a ação, única atividade que ocorre diretamente entre os homens, sem a mediação das coisas ou da matéria, corresponde à condição humana da pluralidade, ao fato de que os homens, e não o Homem, vivem na Terra e habitam o mundo"57.

A ação, enquanto condição humana, desenvolve-se em espaços públicos especificamente destinados ao exercício da cidadania através da discussão política sobre questões de interesse da sociedade, o que pode ser feito através do uso da internet em fóruns virtuais e nas redes sociais, como o facebook.

As novas tecnologias da informação e comunicação podem trazer riscos aos direitos fundamentais, em especial ao direito à intimidade ${ }^{58}$, mas também oferecem oportunidades para o seu desenvolvimento e concretização ${ }^{59}$. Assim, diante desse contexto de expansão digital, não se pode negar que os velhos mecanismos constitucionais de exercício da democracia semidireta (plebiscito, referendo, ação popular e iniciativa popular) já são insuficientes e inadequados para assegurar a plena gerência do povo nos negócios políticos do Estado.

Além disso, Caroline Müller Bitencourt e Eduarda Simonetti Pase aduzem claramente que os meios de exercício da democracia participativa previstos na Constituição Federal de 1988 não são suficientes porque "não se aprofundam as formas de compreensão do fenômeno político e governamental aos destinatários das ações do Estado, que almejem uma sociabilidade maior e mais igualitária nesse processo de tomada de decisões"60.

\footnotetext{
56 ARENDT, Hannah. A condição humana. 11. ed., Rio de Janeiro: Forense Universitária, 2011, p. 08.

57 ARENDT, Hannah. A condição humana. 11. ed., Rio de Janeiro: Forense Universitária, 2011, p. 8.

58 ÁVILA, Ana Paula Oliveira; WOLOSZYN, André Luis. A tutela jurídica da privacidade e do sigilo na era digital: doutrina, legislação e jurisprudência. Revista de Investigações Constitucionais, Curitiba, vol. 4, n. 3. p. 167200, set./dez. 2017. DOI: 10.5380/rinc.v4i3.51295.

59 MOLINARO, Carlos Alberto. Museus necessitam manter a continuidade das suas funções culturais no domínio digital como expressão de um direito cultural (esta missão é desafiadora porque essas instituições necessitam de mais e melhores recursos humanos, financeiros e tecnológicos nem sempre disponíveis). Revista Direitos Fundamentais \& Democracia, Curitiba, v. 23, n. 1, p. 215-241, jan./abr. 2018, p. 227.

60 BITENCOURT, Caroline Müller; PASE, Eduarda Simonetti. A necessária relação entre democracia e controle social: discutindo os possíveis reflexos de uma democracia "não amadurecida" na efetivação do controle social da administração pública. Revista de Investigações Constitucionais, Curitiba, vol. 2, n. 1, p. 293-311, jan./abr. 2015. DOI: http://dx.doi.org/10.5380/rinc.v2i1.43663, p. 302.
} 
É mister a ampliação dos instrumentos de participação no poder pelo povo, uma vez que "grande parte da vida das pessoas acontece online" ${ }^{\prime \prime 1}$. A internet modificou as relações e interações entre as pessoas, com potencialidade de afetar a democracia, de acordo com o contexto político e social ${ }^{62}$.

O momento atual é a da "era dos computadores, e-mails, telefones celulares, televisão por satélite, mídias e redes sociais" ${ }^{\prime 63}$. Como resultado dessas novas tecnologias, tem-se a modificação do modo como os governos se comunicam e interagem com seus cidadãos, propiciando, inclusive, o surgimento da "e-democracia" consistente no uso da tecnologia para aproximar a população do Estado mediante a ampliação das formas de participação popular nas tomadas de decisão da Administração Pública ${ }^{64}$.

O exercício da cidadania, sem a intermediação de partidos ou representantes políticos, é possível graças à tecnologia da informação, notadamente as redes sociais, que são verdadeiras fontes de comunicação de massa. Segundo Diogo de Figueiredo Moreira Neto, "a politização eletrônica abre uma via direta e muito diversificada, que supera comícios e palanques, para expressar a vontade popular independentemente de canais tradicionais midiáticos e, notadamente, partidários" 65 .

A "e-democracia", na lição de William H. Dutton, permite a interação e o diálogo entre cidadãos com pontos de vistas diferentes, estimulando a participação mais informada da população nos debates políticos e na formulação de políticas públicas ${ }^{66}$. $O$ debate político pode ser exercido para além de fronteiras e tempo porque as manifestações locais podem ser divulgadas ao mundo, isto é, ir do local ao global, sem a necessidade de passar pelo nacional ${ }^{67}$.

A internet é um instrumento de difusão rápida de movimentos e opiniões contra-hegemônicos, com ampla possibilidade de ultrapassar os limites da grande mídia

61 RIBEIRO, Samantha Souza de Moura. Internet e democracia: o papel do direito como vetor de integração. In: SIMÃO FILHO, Adalberto; PEREIRA JÚNIOR, Antônio Jorge; NASCIMENTO, Valéria Ribas dos (Coord.). Direito e novas tecnologias II. Florianópolis: CONPEDI, p. 357-378, 2014, p. 357.

62 RIBEIRO, Samantha Souza de Moura. Internet e democracia: o papel do direito como vetor de integração. In: SIMÃO FILHO, Adalberto; PEREIRA JÚNIOR, Antônio Jorge; NASCIMENTO, Valéria Ribas dos (Coord.). Direito e novas tecnologias II. Florianópolis: CONPEDI, p. 357-378, 2014, p. 359.

63 MOLINARO, Carlos Alberto. Museus necessitam manter a continuidade das suas funções culturais no domínio digital como expressão de um direito cultural (esta missão é desafiadora porque essas instituições necessitam de mais e melhores recursos humanos, financeiros e tecnológicos nem sempre disponíveis). Revista Direitos Fundamentais \& Democracia, Curitiba, v. 23, n. 1, p. 215-241, jan./abr. 2018, p. 223.

64 DUTTON, William H.. Social transformation in a information society: rethinking acess to you and the world. United Nations Educational, Scientific and Cultural Organization - UNESCO. Paris, 2004, p. 98.

65 MOREIRA NETO, Diogo de Figueiredo. Relações entre poderes e democracia: e crise e superação. Belo Horizonte: Fórum, 2014, p. 48.

66 DUTTON, William H.. Social transformation in a information society: rethinking acess to you and the world. United Nations Educational, Scientific and Cultural Organization - UNESCO. Paris, 2004, p. 103.

67 RIBEIRO, Samantha Souza de Moura. Internet e democracia: o papel do direito como vetor de integração. In: SIMÃO FILHO, Adalberto; PEREIRA JÚNIOR, Antônio Jorge; NASCIMENTO, Valéria Ribas dos (Coord.). Direito e novas tecnologias II. Florianópolis: CONPEDI, p. 357-378, 2014, p. 366. 
e, por isso, de se tornar num instrumento de disseminação de poder ${ }^{68}$. O sociólogo espanhol Manuel Castells, em entrevista à Folha de São Paulo no dia 21 de setembro de 2010, aduziu que a internet amedronta o poder político porque

[...] o poder sempre esteve baseado no controle e, às vezes, na manipulação da informação. O grau de autonomia das pessoas para se comunicar, informar e organizar suas próprias redes de sociabilidade é muito mais potente com a internet. Ela é a construção da autonomia da sociedade civil. Os governos sempre tiveram horror a isso69.

A tecnologia, por meio da internet, permitiu a ampliação e a abertura de novos canais de participação política direta do cidadão na gestão da coisa pública, isto é, sem intermediários ${ }^{70}$. A internet facilita o acesso à informação e a transparência das ações governamentais, ampliando qualitativa e quantitativamente o controle social do Estado porque mais pessoas com perspectivas, visões de mundo e formações diversas poderão observar o Poder Público, de modo que a tecnologia pode ser usada para empoderar o cidadão, que passa a agir politicamente e a influenciar a agenda do Estado ${ }^{71}$.

A participação social nos processos de tomada de decisão do Poder Público aproxima a comunidade do Estado e permite que as escolhas administrativas sejam feitas a partir da análise e da ponderação das necessidades sociais apresentadas pelo povo à Administração Pública e recaiam sobre aquelas mais consentâneas com o dever de eficiência ${ }^{72}$.

O controle social da Administração Pública depende, porém, da publicidade dos atos estatais, da transparência administrativa e do acesso à informação ${ }^{73}$, que são facilitados pelo uso da internet. Afinal, como explicita Jaime Rodríguez-Arana Muñoz, as novas tecnologias oferecem ao cidadão o acesso facilitado à informação pública, propiciam maior transparência dos dados públicos e, especialmente e permitem o cidadão

68 RIBEIRO, Samantha Souza de Moura. Internet e democracia: o papel do direito como vetor de integração. In: SIMÃO FILHO, Adalberto; PEREIRA JÚNIOR, Antônio Jorge; NASCIMENTO, Valéria Ribas dos (Coord.). Direito e novas tecnologias II. Florianópolis: CONPEDI, p. 357-378, 2014, p. 366-367.

69 CASTELLS, Manuel. Se um país não quer mudar, não é a rede que irá mudá-lo. Folha de São Paulo, São Paulo, 21 de setembro de 2010. Entrevista concedida a Alec Duarte. Disponível em: <http://www1.folha.uol. com.br/fsp/poder/po2109201022.htm>. Acesso em 04 de novembro de 2017.

70 NOGUEIRA, Juliana Pires Ferreira; CASTRO, Carlos Portiara. Internet, democracia e comunicação do governo: análise da página do facebook do Portal Brasil da Presidência da República. Revista de Estudos da Comunicação, Curitiba, v. 15, n. 37, p. 134-151, jan./mar/ 2014, p. 142.

71 RIBEIRO, Samantha Souza de Moura. Internet e democracia: o papel do direito como vetor de integração. In: SIMÃO FILHO, Adalberto; PEREIRA JÚNIOR, Antônio Jorge; NASCIMENTO, Valéria Ribas dos (Coord.). Direito e novas tecnologias II. Florianópolis: CONPEDI, p. 357-378, 2014, p. 367.

72 MARTINS JÚNIOR, Wallace Paiva. Transparência administrativa: publicidade, motivação e participação popular. 2. ed.., São Paulo: Saraiva, 2010, p. 336.

73 MARTINS JÚNIOR, Wallace Paiva. Transparência administrativa: publicidade, motivação e participação popular. 2. ed.., São Paulo: Saraiva, 2010, p. 331. 
participar na tomada de decisões pelo Estado, propiciando, em suma, o bom governo e a boa administração ${ }^{74}$.

A publicidade e a transparência administrativa são da essência do Estado Social e Democrático de Direito, uma vez que os atos do Poder Público devem ser do conhecimento geral da população. Aliás, Norberto Nobbio define a democracia como o "poder em público", para indicar que os governantes são obrigados a tomarem suas decisões às claras e permitam que os governados vejam tais escolhas estatais ${ }^{75}$.

Os princípios da publicidade e da transparência não são conceitos sinônimos. A publicidade é a marca daquilo que é público e não mantido em sigilo, ao passo que a transparência é atributo do que é claro, límpido, cristalino, de modo que os atos do Estado devem ser públicos e transparentes, isto é, devem ser levados a conhecimento de todos e permitir que os interessados possam enxergar com clareza, inclusive de linguagem, seu conteúdo a fim de seja possível efetivar o controle ${ }^{76}$.

Tais princípios constitucionais permitem a visibilidade das atividades administrativas do Estado e o acesso à informação pública pelos cidadãos, propiciando, destarte, a fiscalização e o controle da Administração Pública pela população, além de dificultar a corrupção e o desvio de poder.

No Brasil, o art. $8^{\circ}$ da Lei N.o 12.527/2011 (Lei de Acesso à Informação) impõe aos órgãos e entidades públicas a obrigação de promover, independentemente de requerimentos, a divulgação em local de fácil acesso, inclusive em sítios oficiais da rede mundial de computadores (internet), de informações de interesse coletivo ou geral por eles produzidas ou custodiadas ${ }^{77}$.

O art. 48 da Lei Complementar N. 101/2000 (Lei de Responsabilidade Fiscal) aduz que são instrumentos de transparência da gestão fiscal, aos quais será dada ampla divulgação, inclusive em meios eletrônicos de acesso público: os planos, orçamentos e leis de diretrizes orçamentárias; as prestações de contas e o respectivo parecer prévio; o Relatório Resumido da Execução Orçamentária e o Relatório de Gestão Fiscal; e as versões simplificadas desses documentos ${ }^{78}$.

74 RODRÍGUEZ-ARANA MUÑOZ, Jaime. Direito fundamental à boa administração pública. Belo Horizonte: Fórum, 2012, 65.

75 BOBBIO, Norberto. Teoria geral da política: a filosofia política e as lições dos clássicos. Rio de Janeiro: Elsevier, 2000, p. 386.

76 MOTTA, Fabrício. Notas sobre publicidade e transparência na Lei de Responsabilidade Fiscal no Brasil. A\&C Revista de Direito Administrativo \& Constitucional, Belo Horizonte, ano 7, n. 30, p. 91-108, out./dez. 2007. Disponível em: <http://bid.editoraforum.com.br/bid/PDI0006.aspx?pdiCntd=49819>. Acesso em: 5 nov. 2015.

77 BRASIL. Lei $n .12 .527$, de 18 de novembro de 2011. Regula o acesso a informações previsto no inciso XXXIII do art. 5ㅜ, no inciso Il do $\S 3^{\circ}$ do art. 37 e no $§ 2^{\circ}$ do art. 216 da Constituição Federal; altera a Lei no 8.112 , de 11 de dezembro de 1990; revoga a Lei no 11.111, de 5 de maio de 2005, e dispositivos da Lei no 8.159, de 8 de janeiro de 1991; e dá outras providências. Diário Oficial da República Federativa do Brasil, Poder Executivo, Brasília, DF, 18 de novembro de 2011. Edição Extra.

78 BRASIL. Lei Complementar n. 101, de 04 de maio de 2000. Estabelece normas de finanças públicas voltadas para a responsabilidade na gestão fiscal e dá outras providências. Diário Oficial da República Federativa do Brasil, Poder Executivo, Brasília, DF, 05 de maio de 2000. 
Ademais, a União, os Estados, o Distrito Federal e os Municípios são obrigados a publicar na internet, especificamente no chamado portal da transparência, os dados relativos à execução orçamentária e financeira, com informações específicas sobre receitas e despesas, transferências voluntárias, salários, cargos e lotação dos servidores, diárias, convênios, dentre outras informações ${ }^{79}$, permitindo-se, com isso, que os cidadãos possam exercer, com a obtenção da informação pública, o controle da Administração Pública.

A legislação brasileira impõe o uso da internet como ferramenta de publicidade dos atos do Poder Público, facilitando, por consequência, o acesso à informação pública, de modo que, como averba Têmis Limberger, "por meio da informação disponível por meio eletrônico, desenvolve-se um controle preventivo, estimula-se a participação popular, torna-se o exercício do poder mais transparente e, portanto, mais democrático"80.

Embora a efetividade do controle social do Estado através da tecnologia dependa primordialmente do acesso à internet ${ }^{81}$, que é considerado um direito fundamental porque promove a dignidade humana, na medida em que permite o exercício da cidadania e dos direitos políticos, notadamente o controle da atuação estatal pelos cidadãos $^{82}$, não se pode negar que a tecnologia, por meio da internet, facilita o controle e a fiscalização dos gastos da Administração Pública pelo povo.

E o controle popular da Administração Pública influencia, por sua vez, a tomada de decisões do Poder Público, especialmente na seara orçamentário-financeira, e promove a diminuição dos desvios de recursos públicos e da corrupção, contribuindo, portanto, para a efetividade dos direitos fundamentais consagrados na Constituição Federal através da minimização da reserva do possível.

Enfim, a internet ampliou o grau de publicidade e de transparência administrativa e facilitou o acesso do cidadão à informação. E a maior visibilidade da gestão pública aumenta quantitativa e qualitativamente o controle social e, por isso, serve de fator psicológico de desestímulo à corrupção, ao desvio de poder e à má aplicação dos recursos públicos, minimizando, por via de consequência, os efeitos da reserva do possível e maximizando a concretização dos direitos fundamentais.

\footnotetext{
79 CAMPOS, Rosana; PAIVA, Denise; GOMES, Suely. Gestão da informação pública: um estudo sobre o Portal Transparência Goiás. Sociedade e Estado, Brasília, v. 28, n. 2, p. 421-446, maio/ago. 2013, p. 436.

80 LIMBERGER, Têmis. Transparência administrativa e novas tecnologias: o dever de publicidade, o direito a ser informado e o princípio democrático. Revista de Direito Administrativo, Belo Horizonte, N. 244, p. 248-263, 2007, p. 263.

81 O direito fundamental de acesso à internet não será aqui analisado porque tal tema foge dos objetivos da presente pesquisa.

82 HARTMANN, Ivar Alberto Martins. O acesso à internet como direito fundamental. Revista de Derecho Informático, n. 118, maio/2008. Disponível em: http://www3.pucrs.br/pucrs/files/uni/poa/direito/graduacao/ tcc/tcc2/trabalhos2007_1/ivar_hartmann.pdf. Acesso em 07 de junho de 2018.
} 


\section{CONCLUSÃO}

A tecnologia contribuiu decisivamente, sobretudo após a Segunda Guerra Mundial, para a intensificação dos impactos negativos da interferência do ser humano na natureza, demonstrando a necessidade de conciliar o desenvolvimento econômico e social com a preservação e a proteção do meio ambiente.

A crise ambiental fez surgir a necessidade de uma proteção jurídica efetiva do meio ambiente. Nesta perspectiva, a Constituição Federal consagrou o direito fundamental ao meio ambiente ecologicamente equilibrado, impondo ao Estado o dever fundamental de garantir e proteger o meio ambiente, obrigando o Poder Público a adotar medidas efetivas e adequadas de proteção ao meio ambiente.

Ocorre que, a concretização do direito ao meio ambiente sadio envolve o dispêndio de dinheiro público e os recursos são limitados, daí porque ser sustentado que o efetivo exercício dos direitos fundamentais depende de disponibilidade financeira do Estado. A reserva do possível deve ser levada a sério, o que significa que cabe ao Estado utilizar os recursos públicos disponíveis com probidade e eficiência e aos cidadãos controlar os gastos da Administração Pública.

Nesse contexto, a tecnologia permitiu a ampliação e a abertura de novos canais de participação política do cidadão na gestão da coisa pública e no controle da Administração Pública, uma vez que a internet facilita o acesso à informação e a transparência das ações governamentais.

A maior visibilidade da gestão da coisa pública, proporcionada pela tecnologia, aumenta quantitativa e qualitativamente o controle social e, por isso, serve de desestímulo à prática de atos de improbidade administrativa e de crimes contra a Administração Pública.

Portanto, a tecnologia pode ser utilizada como ferramenta de minimização da reserva do possível e de maximização da efetividade dos direitos fundamentais, especialmente os sociais e ambientais, mediante a publicidade e a transparência dos atos do Poder Público e da participação popular na internet.

\section{REFERÊNCIAS}

ABRAMOVICH, Víctor; COURTIS, Christian. Los derechos sociales como derechos exigibles. 2. ed.. Madrid: Trotta, 2004.

ARENDT, Hannah. A condição humana. 11. ed., Rio de Janeiro: Forense Universitária, 2011.

ARONNE, Ricardo. Sistema jurídico e unidade axiológica: os contornos metodológicos do direito civil constitucional. Revista do Instituto do Direito Brasileiro, Lisboa, Ano 2, n. 1, p. 73-113, 2013. 
ARONNE, Ricardo; MORAES, Denise Bermudez de Oliveira. A valsa do leviatã pós-moderno: velhos cisnes ônticos sobre novos lagos epistêmicos. Revista da Faculdade de Direito - UFPR, Curitiba, n. 56, p. 127-140, 2012.

ÁVILA, Ana Paula Oliveira; WOLOSZYN, André Luis. A tutela jurídica da privacidade e do sigilo na era digital: doutrina, legislação e jurisprudência. Revista de Investigações Constitucionais, Curitiba, vol. 4, n. 3. p. 167-200, set./dez. 2017. DOI: 10.5380/rinc.v4i3.51295.

BAGGIO, Andreza Cristina. A sociedade de risco e a confiança nas relações de consumo. Revista de Direito Econômico e Socioambiental, Curitiba, v. 1, n.1, p. 127-147, jan./jun. 2010.

BARCELLOS, Ana Paula de. A eficácia jurídica dos princípios constitucionais: o princípio da dignidade da pessoa humana. 2. ed.. Rio de Janeiro: Renovar, 2008.

BARROSO, Luís Roberto. Curso de direito constitucional contemporâneo: os conceitos fundamentais e a construção do novo modelo. 4. ed.. São Paulo: Saraiva, 2013.

BAUMAN, Zygmunt. Vida para o consumo: a transformação das pessoas em mercadoria. Rio de Janeiro: Zahar, 2008.

BECK, Ulrich. Ecological Politics in an Age of Risk. Londres: Polity Publications, 1995.

BECK, Ulrich. Sociedade de risco: rumo a uma outra modernidade. São Paulo: 34, 2010.

BITENCOURT, Caroline Müller; PASE, Eduarda Simonetti. A necessária relação entre democracia e controle social: discutindo os possíveis reflexos de uma democracia "não amadurecida" na efetivação do controle social da administração pública. Revista de Investigações Constitucionais, Curitiba, vol. 2, n. 1, p. 293-311, jan./abr. 2015.

BOBBIO, Norberto. Teoria geral da política: a filosofia política e as lições dos clássicos. Rio de Janeiro: Elsevier, 2000.

BOUDRILLARD, Jean. A sociedade de consumo. 3.ed. Lisboa: Edições 70, 2011.

BRASIL. Lei n. 12.527, de 18 de novembro de 2011. Regula o acesso a informações previsto no inciso XXXIII do art. 5ำ no inciso II do $\S 3 \circ$ do art. 37 e no $\S 2^{\circ}$ do art. 216 da Constituição Federal; altera a Lei no 8.112, de 11 de dezembro de 1990; revoga a Lei no 11.111, de 5 de maio de 2005, e dispositivos da Lei no 8.159, de 8 de janeiro de 1991; e dá outras providências. Diário Oficial da República Federativa do Brasil, Poder Executivo, Brasília, DF, 18 de novembro de 2011. Edição Extra.

BRASIL. Lei Complementar n. 101, de 04 de maio de 2000. Estabelece normas de finanças públicas voltadas para a responsabilidade na gestão fiscal e dá outras providências. Diário Oficial da República Federativa do Brasil, Poder Executivo, Brasília, DF, 05 de maio de 2000.

BRASIL. Ministério do Meio Ambiente. Consumo sustentável: manual de educação. Brasília: Consumers International/MMA/MEC/IDEC, 2005. Disponível em: <http://portal.mec.gov.br/dmdocuments/publicacao8.pdf $>$. 
BRESSER-PEREIRA, Luiz Carlos. Revoluções utópicas dos anos 60: a revolução estudantil e a revolução política na igreja. 3. ed. São Paulo: Editora 34, 2006.

CALIENDO, Paulo. Limitações constitucionais ao poder com finalidade extrafiscal. Nomos - Revista do Programa de Pós-Graduação em Direito da Universidade Federal do Ceará. vol. 33, n. 02, p. 171-206, jul./dez. 2013.

CALIENDO, Paulo. Reserva do possível, direitos fundamentais e tributação. In: SARLET, Ingo Wolfgang; TIMM, Luciano Benetti (org.). Direitos fundamentais, orçamento e "reserva do possível". Porto Alegre: Livraria do Advogado, p. 195-208, 2008.

CANOTILHO, José Joaquim Gomes. Direito constitucional e teoria da Constituição. 7. ed., Coimbra: Almedina, 2011.

CASTELLS, Manuel. Se um país não quer mudar, não é a rede que irá mudá-lo. Folha de São Paulo, São Paulo, 21 de setembro de 2010. Entrevista concedida a Alec Duarte. Disponível em: <http:// www1.folha.uol.com.br/fsp/poder/po2109201022.htm>.

DUTT, Mallika; RASUL, Nadia. Conscientização digital: uma análise das oportunidades e dos riscos enfrentados pelos ativistas de direitos humanos no Brasil. SUR - Revista Internacional de Direitos Humanos, vol. 11, n. 20, p. 441-451, jun. 2014.

DUTTON, William H.. Social transformation in a information society: rethinking acess to you and the world. United Nations Educational, Scientific and Cultural Organization - UNESCO. Paris, 2004.

EFING, Antônio Carlos; PAIVA; Leonardo Lindroth de. Consumo e obsolescência programada: sustentabilidade e responsabilidade do fornecedor. Revista de Direito, Globalização e Responsabilidade nas Relações de Consumo, Curitiba, v. 2, n. 2, p. 117-135, jul./dez. 2016.

EFING, Antônio Carlos; RESENDE, Augusto César Leite de. Educação para o consumo consciente: um dever do Estado. Revista de Direito Administrativo - RDA, Rio de Janeiro, v. 269, p. 197-224, maio/ago. 2015.

EHRHARDT JÚNIOR, Marcos. Acertos e desacertos do processo de constitucionalização dos direitos: uma reflexão sobre os perigos da ubiquidade constitucional no direito civil brasileiro. Revista do Instituto do Direito Brasileiro, Lisboa, Ano 1, n. 1, p. 833-865, 2012.

FAJARDO, Elias. Consumo consciente, comércio justo: conhecimento e cidadania como fatores econômicos. Rio de Janeiro: Senac Nacional, 2010.

GIDDENS, Anthony. As consequências da modernidade. Tradução: Raul Fiker. São Paulo: UNESP, 1991.

HARTMANN, Ivar Alberto Martins. O acesso à internet como direito fundamental. Revista de Derecho Informático, n. 118, maio/2008. Disponível em: <http://www3.pucrs.br/pucrs/files/uni/ poa/direito/graduacao/tcc/tcc2/trabalhos2007_1/ivar_hartmann.pdf >. 
HESSE, Konrad. A força normativa da Constituição, Tradução: Gilmar Ferreira Mendes, Sérgio Antônio Frabris Editor, Porto Alegre, 1991.

HOLMES, Stephen; SUNSTEIN, Cass R.. The cost of rights: why liberty depends on taxes. New York: W. W. Norton \& Company, 1999.

LIMBERGER, Têmis. Transparência administrativa e novas tecnologias: o dever de publicidade, o direito a ser informado e o princípio democrático. Revista de Direito Administrativo, Belo Horizonte, N. 244, p. 248-263, 2007.

MACHADO, Carlos Augusto Alcântara. Fraternidade e Democracia: Considerações sobre os mecanismos de participação popular e fraterna na Carta Constitucional do Brasil de 1988. In: VERONESE, Josiane Rose Petry; OLIVEIRA, Olga Maria Boschi Aguiar de; MOTA, Sergio Ricardo Ferreira. O Direito no Século XXI - $\mathbf{O}$ que a Fraternidade tem a dizer. Florianópolis: Editora Insular, p. 59-71, 2016.

MOLINARO, Carlos Alberto. Museus necessitam manter a continuidade das suas funções culturais no domínio digital como expressão de um direito cultural (esta missão é desafiadora porque essas instituições necessitam de mais e melhores recursos humanos, financeiros e tecnológicos nem sempre disponíveis). Revista Direitos Fundamentais \& Democracia, Curitiba, v. 23, n. 1, p. 215-241, jan./abr. 2018.

NOGUEIRA, Juliana Pires Ferreira; CASTRO, Carlos Portiara. Internet, democracia e comunicação do governo: análise da página do facebook do Portal Brasil da Presidência da República. Revista de Estudos da Comunicação, Curitiba, v. 15, n. 37, p. 134-151, jan./mar/ 2014.

MARCUSE, Herbert. $\mathbf{O}$ homem unidimensional: estudos da ideologia da sociedade industrial avançada. São Paulo: EDIPRO, 2015.

MARTINS JÚNIOR, Wallace Paiva. Transparência administrativa: publicidade, motivação e participação popular. 2. ed.., São Paulo: Saraiva, 2010.

MOLINARO, Carlos Alberto; SARLET, Ingo Wolfgang. Sociedade em rede, internet e estado de vigilância: algumas aproximações. Revista da AJURIS, Porto Alegre, vol. 40, n. 132, p. 63-87, dezembro de 2013.

MÖLLER, Max. Teoria geral do neoconstitucionalismo: bases teóricas do constitucionalismo contemporâneo. Porto Alegre: Livraria do Advogado, 2011.

MOREIRA NETO, Diogo de Figueiredo. Relações entre poderes e democracia: e crise e superação. Belo Horizonte: Fórum, 2014.

MOTTA, Fabrício. Notas sobre publicidade e transparência na Lei de Responsabilidade Fiscal no Brasil. A\&C Revista de Direito Administrativo \& Constitucional, Belo Horizonte, ano 7, n. 30, p. 91-108, out./dez. 2007. Disponível em: <http://bid.editoraforum.com.br/bid/PDI0006. aspx?pdiCntd $=49819>$. 
NABAIS, José Casalta. A face oculta dos direitos fundamentais: os deveres e os custos dos direitos. Revista de Direito Público da Economia - RDPE. Belo Horizonte, ano 5, n. 20, p. 153-181, out./ dez. 2007.

PORTILHO, Fátima. Sustentabilidade ambiental, consumo e cidadania. 2.ed. São Paulo: Cortez, 2010.

RIBEIRO, Samantha Souza de Moura. Internet e democracia: o papel do direito como vetor de integração. In: SIMÃO FILHO, Adalberto; PEREIRA JÚNIOR, Antônio Jorge; NASCIMENTO, Valéria Ribas dos (Coord.). Direito e novas tecnologias II. Florianópolis: CONPEDI, p. 357-378, 2014.

RODRÍGUEZ-ARANA MUÑOZ, Jaime. Direito fundamental à boa administração pública. Belo Horizonte: Fórum, 2012.

SARLET, Ingo Wolfgang. A eficácia dos direitos fundamentais: uma teoria geral dos direitos fundamentais na perspectiva constitucional. 12. ed.. Porto Alegre: Livraria do Advogado, 2015.

SARLET, Ingo Wolfgang. Dignidade da pessoa humana e direitos fundamentais na Constituição Federal de 1988. 9. ed.. Porto Alegre: Livraria do Advogado, 2012.

SARLET, Ingo Wolfgang. Direitos fundamentais a prestações sociais e crise: algumas aproximações. Espaço jurídico. v. 16, n. 2, p. 459-488, jul./dez. 2015.

SARLET, Ingo Wolfgang; FENSTERSEIFER, Tiago. Direito constitucional ambiental: Constituição, direitos fundamentais e proteção do ambiente. 2. ed.. São Paulo: Revista dos Tribunais, 2012.

SARLET, Ingo Wolfgang; FIGUEIREDO, Mariana Filchtiner. Reserva do possível, mínimo existencial e direito à saúde: algumas aproximações. In: SARLET, Ingo Wolfgang; TIMM, Luciano Benetti (orgs). Direito Fundamentais: orçamento e reserve do possível. 2. ed.., Porto Alegre: Livraria do Advogado, p. 13-50, 2013.

SILVEIRA, Clóvis Eduardo Malinverni da. Processos coletivos para a tutela do risco ecológico: a construção de um patrimônio comum coletivo. 2011. 441f. Tese (Doutorado em Direito) - Universidade Federal de Santa Catarina, Centro de Ciências Jurídicas. Programa de Pós-Graduação em Direito. Florianópolis. 